\title{
ЕКОЛОГІЧНА БЕЗПЕКА: ЕКСПЛУАТАЦІЯ ІРУНТІВ У ЧЕРКАСЬКІЙ ОБЛАСТІ
}

У статті обгрунтовано необхідність моніторингу змін стану грунтового покриву i формування відповідних програм із призупинення деградації й відтворення родючості. Визначено, що для оцінювання якості відношення виробників продукції рослинництва до збереження грунту слід враховувати не тільки кількість внесення органічних та мінеральних добрива, але й їхнє співвідношення (коефіцієнт екологічної збалансованості).

Проаналізовано склад основних полютантів, що надходять в атмосферне повітря, грунт i грунтові води від тваринницьких підприємств. Встановлено, що для поліпшення екологічної ситуації та виробництва якісної продукції тваринництва необхідно використовувати екологічно безпечні технології та впроваджувати сучасні технології з утилізації відходів, осадів стічних вод, дотримання всіх санітарних та ветеринарних вимог згідно з нормативно-правовим регулюванням.

Визначено, що коефіцієнт екологічної збалансованості внесення органічних та мінеральних добрив у Черкаській області в 1,7 раза вищий від аналогічного показника по Україні, що відповідно у 2,6 та 4,3 раза нижче від існуючих норм. Внесення мінеральних добрив по Черкаській області у 2,3, а по Україні у 2,6 раза менше від норми. Внесення органічних добрив по Черкаській області у 6,7, а по Україні у 16,0 раза менше від норми.

Застосовуючи коефіцієнт екологічної збалансованості внесення органічних та мінеральних добриву рослинництві, вивчили рівень збереження грунтів Черкаської області. Виявлено, що коефіцієнт рівня збереження грунтів Черкаської області становить 0,39, а в Україні - 0,23, що, як на рівні Черкаської області, так і на рівні країни, призводить до деградації грунтів і свідчить про низьку технологічно-екологічну культуру виробників сільськогосподарської продукції.

Ключові слова: органічні добрива, мінеральні добрива, грунт, коефіцієнт екологічної збалансованості, сільськогосподарське виробництво.

Постановка проблеми. Рівень розвитку економічної безпеки країни безпосередньо впливає на стан екологічної безпеки, що характеризує рівень господарської, технологічної, виробничої, соціальної, політичної та безпосередньо екологічної культури. Стійкий розвиток країни неможливий без відповідної, на всіх рівнях діяльності, еволюції системи заходів щодо забезпечення екологічної безпеки. При цьому три базові категорії безпеки (територіальнопросторова безпека, енергетична безпека та продовольча безпека) потребують збереження як загального, так і специфічного для кожної з них рівня екологічної безпеки [1].

Грунтовий покрив є одним із основних компонентів довкілля, що виконує життєво важливі біосферні функції. Грунти беруть участь у процесі регулювання якості поверхневих і підземних вод, складу атмосферного повітря, $є$ середовищем існування великої кількості живих організмів на поверхні суходолу, забезпечують сприятливе середовище для людини та виробництва сільськогосподарської продукції. У рішеннях всесвітньої конференції 3 навколишнього середовища і розвитку (1992 р., Ріо-де-Жанейро) було зазначено, що охорона і раціональне використання грунтів мають стати центральною ланкою державної політики, оскільки їхній стан визначає характер життєдіяльності людства і вирішальним чином впливає на довкілля.

Грунтовий покрив України на $60 \%$ складається з чорноземів - унікальних за своєю будовою, властивостями і потенційною родючістю грунтів. Їм властивий глибокий гумусований шар, добре виражена зерниста структура, майже ідеальна щільність будови, достатній і помірний запас поживних речовин. На жаль, такі зразкові об'єкти збереглися лише у цілинних умовах. Виявилося, що найкращий у світі чорнозем («царь почв», за Докучаєвим В. В.) дуже вразливий до антропогенного втручання і під дією антропогенних чинників може швидко деградувати [2]. 
Однією із основних складових продовольчої безпеки $є$ галузь тваринництва, яка поряд 3 економічним значенням має i екологічне значення. Тваринництво $\epsilon$ джерелом продуктів харчування, сировини для переробної та промислової галузей. Технологічно перероблений у перегній гній від тварин є одним із основних факторів збереження гумусу грунтів.

Недотримання норм внесення органічних добрив призводить до порушення співвідношення 3 кількісними показниками мінеральних добриві і при цьому негативно впливає на збереження грунтів та фіксує тенденцію на подальше погіршення кількісно-якісних показників гумусу. Разом iз цим технологічно не перероблений, а отже, і не використаний гній від сільськогосподарських тварин негативно впливає на навколишнє середовище.

Аналіз останніх досліджень і публікацій. Викладене вище засвідчує, що у зв'язку 3 інтенсивним використанням земельних ресурсів екологічний стан грунтового покриву України змінюється переважно у небажаному напрямі. Контролювання цих змін і формування відповідних програм із призупинення деградації й відтворення родючості грунтів $\epsilon$ надзвичайно актуальним завданням [2].

Основними показниками, що дають уявлення про технологічну й екологічну культуру виробників сільськогосподарської продукції, $\epsilon$ показники внесення органічних та мінеральних добрив під урожай сільськогосподарських культур. Важливими показниками $є$ кількісні показники внесення мінеральних та органічних добрив на 1 га загальної та посівної площі сільськогосподарських культур. Ці показники можуть слугувати якісними індикаторами оцінки рівня технологічного й екологічного ставлення до збереження родючості грунтів [1].

До недавнього часу не існувало досконалих комплексних економіко-екологічних показників для визначення якості відношення виробників продукції рослинництва до збереження основного, створеного природою біологічно-виробничого конвеєру - грунту. Використовували аналітичні показники з кількості внесення органічних та мінеральних добрив. Для розв' язання цього питання було розроблено коефіцієнт екологічної збалансованості внесення органічних та мінеральних добриву рослинництві- комплексний показник, що враховує не тільки їхню кількість, але і співвідношення [3].

Постановка завдання. Метою роботи було практичне застосування розробленої методики для визначення рівня збереження грунтів для окремо взятого регіону - Черкаської області, 3 використанням коефіцієнта екологічної збалансованості внесення органічних та мінеральних добрив у рослинництві. А це дасть загальну оцінку ставленню виробників сільськогосподарської продукції до збереження грунтів, що $є$ безумовним віддзеркаленням технологічно-екологічної культури виробників сільськогосподарського виду економічної діяльності.

Виклад основного матеріалу. Основними підгалузями галузі тваринництва є:

- велика рогата худоба;

- свинарство;

- вівчарство;

- птахівництво.

Тваринницькі підприємства $\epsilon$ джерелом надходження в атмосферне повітря таких забруднювальних речовин як вуглекислий газ, аміак, метан, сірководень, меркаптан, аміни, пил i мікроорганізми. Тобто повітряне середовище, що являє собою складний комплекс різноманітних і взаємопов'язаних факторів, накопичуючи шкідливі гази, може негативно впливати на рослин, фізіологічний стан та продуктивність тварин, а також санітарно-побутові умови життя людей.

У повітрі корівників у стійловий період утримання великої рогатої худоби одночасно 3 такими газами (вуглекислий газ та аміак) накопичуються також шкідливі нижчі аліфатичні аміни: метиламін, етиленамін, пропіламін, бутиламін та ізобутиламіни, загальна концентрація в яких досягає величин $0,89 \mathrm{Mг} / \mathrm{m}^{3}$, що здатна спричинити хронічні отруєння у тварин.

Встановлено пряму залежність між вмістом важких металів у грунті, воді та рослинах. Надходження важких металів із водою та кормами в організм тварин сприяе їхньому накопиченню в тканинах. Внаслідок кумулятивної дії вони видаляються 3 організму з продуктами тваринного походження. До організму людини надходить через продукцію тваринництва 13-25\% важких металів від загальної кількості їхнього накопичення в організмі, а 75-87\% - має рослинне походження. Токсичні хімічні елементи, що потрапили в організм тварин, виводяться з нього повільно. Тобто тварини здатні накопичувати важкі метали окремими органами та тканинами. Тому корми, які вирощують навіть на відносно чистих та мало забруднених важкими металами 
грунтах, можуть стати джерелом надходження останніх у надмірній кількості до організму та бути причиною порушення обміну речовин.

Прилеглі до тваринницьких ферм та комплексів території та повітряне середовище зазнають значного токсичного навантаження. Основні принципи 3 вивчення впливу тваринницьких підприємств на довкілля мають формуватися на основі обов'язкового обліку умов формування, вичерпної кількісної і якісної характеристики відходів та продуктів їхньої переробки, ефективності очисних споруд із обробки рідкого гною і стічних вод, а також можливості надходження забруднень в атмосферне повітря, грунти, грунтові води та відкриті водойми [4].

Відходи свинарства містять речовини, спожиті тваринами 3 кормами, через те що лише третину поживних компонентів організм тварини використовує на різноманітні фізіологічні процеси, а також велику кількість мікроорганізмів, що населяють шлунково-кишковий канал тварин і нерідко є збудниками інфекційних хвороб. Фізичний, хімічний та мікробіологічний склад цих відходів залежить від різних чинників, таких як способи утримання та годівлі, відповідність режиму утримання, догляду за тваринами, а також від фізіологічних особливостей самих тварин (вік, вага, стать, порода). Кількість та фізичний і хімічний склад відходів значною мірою залежить від технологій утримання свиней та використання системи видалення відходів із приміщень.

Однією з найважливіших проблем і надалі залишатиметься проблема відходів виробництва продукції свинарства - своєчасне видалення з приміщень, забезпечення належних умов зберігання та переробки на технологічно правильно облаштованих місцях їхнього утилізування. Майбутні інновації у зберіганні гною, переробленні та очищенні стічних вод базуватимуться на біотехнологіях. Створення відповідних мікроорганізмів забезпечить нові можливості для ефективної обробки гною і стічних вод, очищення води, що $\epsilon$ надзвичайно важливим на регіональному рівні для підтримання ефективного водного балансу. Покращення зберігання гною знизить викиди аміаку у місцях його зберігання [5].

Відходи та продукти життєдіяльності птиці мають неприємний запах (понад 45 різних речовин), поширюються на значні відстані до 10 км. Ущільнене розміщення птиці в приміщені, перезволоження підстилки та інші порушення технології утримання створюють умови для анаеробного бродіння посліду. До специфічних і найбільш небезпечних викидів віднесено метилмеркаптан, аміак, диметиламін, сірководень, диметилсульфід, кислоту капронову, альдегід пропіоновий, фенол, пил пуховий, пил комбікормовий, а також діоксид азоту та оксид вуглецю.

Зони розповсюдження специфічних запахів залежать від швидкості і напрямку вітру, температури атмосферного повітря, рельєфу місцевості та наявності лісових насаджень. До факторів впливу на довкілля виробництва птахівничої продукції глобального масштабу можна віднести викиди парникових газів, пов'язаних із використанням енергії в виробничих процесах, життєдіяльністю птиці, накопиченням відходів виробництва. За приблизними оцінками, лише у спеціалізованих господарствах кількість відходів за рік складає: підстилкового та безпідстилкового посліду - близько 5,2 млн тонн.

Проблема надійного захисту навколишнього природного середовища від забруднення пташиним послідом, стічними водами і відходами - актуальна проблема практично для всіх птахівничих господарств України. Для поліпшення екологічної ситуації та виробництва якісної продукції тваринництва необхідно використовувати екологічно безпечні технології та впроваджувати сучасні технології з утилізації відходів, осадів стічних вод, дотримання всіх санітарних та ветеринарних вимог згідно з нормативно-правовим регулюванням [6].

Розвиток тваринництва, з одного боку, забезпечує населення необхідними продуктами харчування, рослинницьку галузь - органічними добривами, що сприяє підвищенню родючості грунту, збільшенню вмісту поживних елементів у ньому, активізує розвиток мікроорганізмів, що беруть активну участь у процесах гумусоутворення, впливають на склад грунтового повітря, цикли перетворення азотовмісних сполук, однією з важливих ланок яких $\epsilon$ фіксація азоту грунтовими мікроорганізмами [7].

Для визначення рівня збереження грунтів у Черкаській області ми використовували розроблений коефіцієнт екологічної збалансованості внесення органічних та мінеральних добрив у рослинництві, який визначають як відношення показника внесених органічних добрив до показника внесених мінеральних добрив, взявши одночасно $з$ фактичними показниками $\mathrm{i}$ нормовані показники [8]:

$$
K_{E 3}=\frac{K_{O \Phi}+K_{M \Phi}}{K_{O H}+K_{M H}},
$$


де $K_{E 3}$ - коефіцієнт екологічної збалансованості внесення органічних та мінеральних добрив на 1 гектар площі;

$K_{O \Phi}-$ коефіцієнт фактичного внесення органічних добрив відносно норми;

$K_{M \Phi}-$ коефіцієнт фактичного внесення мінеральних добрив відносно норми;

$K_{O H}-$ коефіцієнт нормованого внесення органічних добрив;

$K_{M H}-$ коефіцієнт нормованого внесення мінеральних добрив.

Норма внесення органічних добрив становить 80,00 ц/га, а мінеральних - 2,45 ц/га [9]. Внесення органічних та мінеральних добрив у Черкаській області та в Україні а також коефіцієнт їхньої екологічної збалансованості подано у таблиці 1.

Таблиия 1

Коефіцієнт екологічної збалансованості*

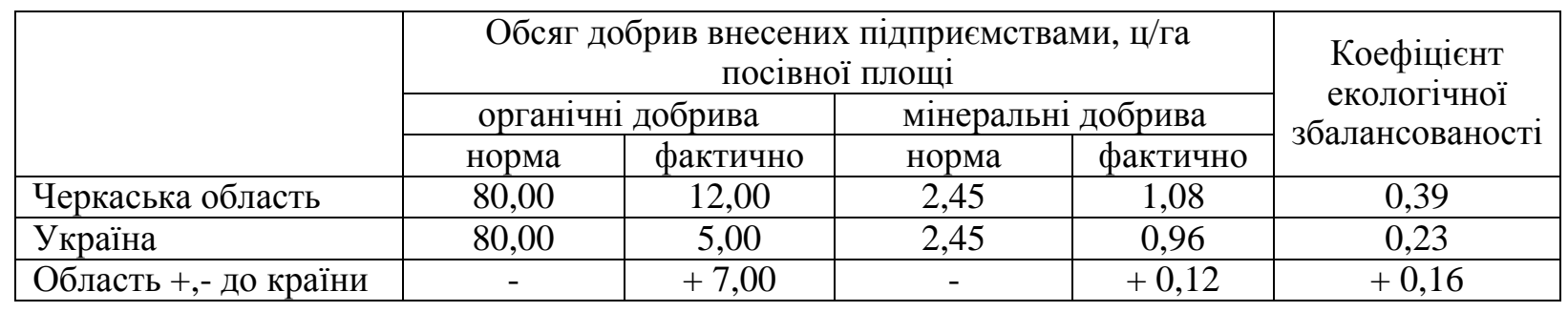

*Таблиия побудована на основі статистичних даних [10, 11].

Як видно з табл. 1, коефіцієнт екологічної збалансованості внесення органічних та мінеральних добрив у Черкаській області у 1,7 раза вищий від аналогічного показника по Україні, що відповідно у 2,6 та 4,3 раза нижче від існуючих норм.

Внесення мінеральних добрив по Черкаській області у 2,3, а по Україні у 2,6 раза менше від норми. Внесення органічних добрив по Черкаській області у 6,7, а по Україні у 16,0 раза менше від норми.

Ці показники є прямими доказами низької технологічної та екологічної культури при виробництві продукції рослинництва та продукції тваринництва зокрема і сільськогосподарського виробництва загалом, як на рівні регіонів, так і на рівні країни.

Для вирішення цього важливого екологічного та економічного питання всі потенціальні можливості, а саме застосування технології переробки екскрементів тваринництва та подальше їхнє використання при вирощуванні сільськогосподарських культур. Потенціальні можливості виробництва перегною у Черкаській області та в Україні представлено у таблиці 2.

Таблиця 2

Потенціальні можливості виробництва перегною у 2017 році**

\begin{tabular}{|c|c|c|c|c|c|}
\hline \multirow[b]{2}{*}{ Вид тварин } & \multirow[b]{2}{*}{$\begin{array}{c}\text { Вихід гною від } \\
\text { однієї тварини за } \\
\text { рік, ц }\end{array}$} & \multicolumn{2}{|c|}{ Черкаська область } & \multicolumn{2}{|c|}{ Україна } \\
\hline & & $\begin{array}{c}\text { поголів’я, } \\
\text { тис. голів }\end{array}$ & $\begin{array}{c}\text { вихід } \\
\text { гноївки, } \\
\text { тис. тонн }\end{array}$ & $\begin{array}{l}\text { поголів’я, } \\
\text { тис. голів }\end{array}$ & $\begin{array}{c}\text { вихід } \\
\text { гноївки, } \\
\text { тис. тонн }\end{array}$ \\
\hline Велика рогата худоба & 55,0 & 176 & 968 & 3682 & 20251 \\
\hline Свині & 16,5 & 386 & 637 & 6669 & 11004 \\
\hline Вівці та кози & 5,0 & 31 & 16 & 1315 & 66 \\
\hline Птиця & 0,7 & 24310 & 1702 & 201700 & 14119 \\
\hline Разом & - & - & 3323 & - & 45440 \\
\hline $\begin{array}{l}\text { Внесено органічних } \\
\text { добрив }\end{array}$ & - & - & 1100 & - & 9163 \\
\hline Використання, \% & - & - & 33,1 & - & 20,2 \\
\hline Накопичення за рік & - & - & 2223 & - & 36277 \\
\hline
\end{tabular}

**Таблиия побудована на основі статистичних даних [10, 11].

Вихід гноївки від сільськогосподарських тварин у Черкаській області становить 3,32, а в Україні 45,44 мільйонів тонн. Використовується для потреб рослинництва - 33,1\% та 20,2\% відповідно. Щорічне накопичення гноївки при виробництві продукції тваринництва перебуває на рівні:

- Черкаська області 2,22 млн тонн;

- Україна 36,28 млн тонн. 
Таке відношення виробників сільськогосподарської продукції, як на рівні Черкаської області, так і на рівні країни, призводить до деградації грунтів і до негативного впливу на навколишнє середовище. А враховуючи те, що така тенденція спостерігається протягом останніх десятиліть, ми уже перейшли межу, за якою перебуває точка неможливого повернення.

Висновки. Розроблення різних методів оцінювання впливу виробників сільськогосподарської продукції на збереження грунтів, а паралельно до цього - і на збереження довкілля спонукатиме застосування дійових технологій перероблення гною різних видів сільськогосподарських тварин на органічні добрива, що у свою чергу дасть можливість підвищити технологічно-екологічну культуру сільськогосподарської діяльності і бережливо ставитися до збереження грунтів та навколишнього середовища.

Аналізування впливу сільськогосподарської діяльності може мати й інші науково-практичні підходи, які необхідно розробляти для всіх рівнях господарсько-адміністративної діяльності.

\section{Література}

1 Бужин О. О. Сільськогосподарське виробництво в системі екологічної безпеки / О. О. Бужин // Актуальні проблеми економіки. - 2013. - № 9 (147). - С. 158-164.

2 Балюк С. А. Екологічний стан грунтів України / С. А. Балюк, В. В. Медведєв, М. М. Мірошниченко, Є. В. Скрильник, Д. О. Тимченко, А. І. Фатєєв, А. О. Христенко, Ю. Л. Цапко // Український географічний журнал. - 2012. - № 2. - С. 38-42.

3 Бужин О. О. Екологічна безпека: коефіцієнт екологічної збалансованості внесення органічних та мінеральних добрив / О. О. Бужин // Науковий журнал «Молодий вчений». - 2015. № 2. Ч. I. - C. 127-130.

4 Яремчук О. С. Екологічні та санітарно-гігієнічні аспекти тваринницьких підприємств/ О. С. Яремчук, М. О. Захаренко, І. М. Курбатова // Збірник наукових праць ВНАУ. - 2010. № 5 (45). - С. 152-154.

5 Жукорський О. М. Галузь свинарства - реальна та прогнозована загроза для довкілля / О. М. Жукорський, О. В. Никифорук // Агроекологічний журнал. -2013. - № 3. - С.102-106.

6 Бородай В. П. Екологічна оцінка стану довкілля в зонах виробництва продукції птахівництва / В. П. Бородай, О.В.Тертична, М. П. Кейван, О. П. Бригас, I. В. Масберг, О. І. Мінералов // Сучасне птахівництво. - 2014. - № 4. - С. 22-25.

7 Палапа Н. В. Промислове тваринництво: еколого-економічні наслідки / Н. В. Палапа, Н. Б. Пронь, О. В. Устименко // Збалансоване природокористування. - 2016. - № 3. - С. 64-67.

8 Бужин О. О. Екологічна безпека: коефіцієнт екологічної збалансованості внесення органічних та мінеральних добрив / О. О. Бужин // Науковий журнал «Молодий вчений». - 2015. № 2. Ч. I. - C. 127-130.

9 Шебанін В. С. Трансформація земельних відносин і землекористування в Україні / В. С. Шебанін, О. В. Шебаніна, I. І. Черевен // Інституціональні засади трансформацій в аграрній сфері : збірник матеріалів Тринадцятих річних зборів Всеукраїнського конгр. вчен. економістіваграрників (м. Київ, 20-21.06.2011) / Редкол.: П. Т. Саблук та ін. - К. : ННЦ IAE, 2011. - С. $462-$ 466.

10 Внесення мінеральних та органічних добрив під урожай сільськогосподарських культур у 2017 році [Електронний ресурс] - Режим доступу: http://www.ck.ukrstat.gov.ua/source/ arch/2018/dobriva_18.pdf.

11 Статистичний щорічник України за 2016 рік / Держ. комітет статистики України. - К. : 2017. $-610 \mathrm{c}$.

O. Buzhyn, A. Shvydenko, O. Kulitsa, R. Zaiets, V. Hora Cherkasy Institute of Fire Safety named after Chornobyl Heroes of National University of Civil Defence of Ukraine

\section{ENVIRONMENTAL SAFETY: SOILS EXPLOITATIONIN IN CHERKASY OBLAST}

The article substantiates the necessity of monitoring the changes in soil cover and the development of appropriate programs to suspend soil degradation and reproduce soil fertility. The authors have defined 
that the quality assessment of soil treatment by the producers of plant products and soil conservation should take into account not only the amount of applied organic and mineral fertilizers, but also their correlation (ecological balance index).

The composition of the major pollutants, emitted into the atmospheric air, soil and groundwater by livestock enterprises, has been analyzed. It has been defined that in order to improve the ecological situation and produce the high-quality livestock products, it is necessary to use environmentally sound technologies and implement modern technologies for waste and sewage sludge disposal, and comply with all sanitary and veterinary requirements in accordance with the legal and regulatory framework.

It has been defined that the ecological balance indices for applying organic and mineral fertilizers in Cherkasy oblast are 1.7 times higher than the similar indices within Ukraine, which are respectively 2.6 and 4.3 times below the existing norms. The application of mineral fertilizers in Cherkasy oblast is 2.3 and in Ukraine 2.6 times below the norm. The introduction of organic fertilizers in Cherkasy oblast is 6.7 and within Ukraine 16.0 times below the norm.

Soil conservation level in Cherkasy oblast has been studied based on the ecological balance index for the introduction of organic and mineral fertilizers in plant production. It has been found out that the level of soil conservation in Cherkasy oblast is 0.39 , and in Ukraine -0.23 , which, both at the level of Cherkasy oblast and at the state level, leads to the degradation of soils and indicates low technological and ecological culture of agricultural producers.

Key words: organic fertilizers, mineral fertilizers, soil, ecological balance index, agricultural production.

\section{References}

1 Buzhyn O. O. Silskohospodarske vyrobnytstvo v systemi ekolohichnoi bezpeky / O. O. Buzhyn // Aktualni problemy ekonomiky. 2013. - № 9(147). - S. 158-164.

2 Baliuk S. A. Ekolohichnyi stan gruntiv Ukrainy / S. A. Baliuk, V. V. Medvediev, M. M. Miroshnychenko, Ye. V. Skrylnyk, D. O. Tymchenko, A. I. Fatieiev, A. O. Khrystenko, Yu. L. Tsapko // Ukrainskyi heohrafichnyi zhurnal - 2012. - № 2. - S. 38-42.

3 Buzhyn O. O. Ekolohichna bezpeka: koefitsiient ekolohichnoi zbalansovanosti vnesennia orhanichnykh ta mineralnykh dobryv / O. O. Buzhyn // Naukovyi zhurnal «Molodyi vchenyi». - 2015. №2. Ch.I. - S. 127-130.

4 Iaremchuk O. S. Ekolohichni ta sanitarno-hihiienichni aspekty tvarynnytskykh pidpryiemstv/ O. S. Yaremchuk, M. O. Zakharenko, I. M. Kurbatova // Zbirnyk naukovykh prats VNAU. 2010. №5 (45). - S. 152-154.

5 Zhukorskyi O. M. Haluz svynarstva - realna ta prohnozovana zahroza dlia dovkillia / O. M. Zhukorskyi, O. V. Nykyforuk // Ahroekolohichnyi zhurnal. - 2013. - № 3. - S.102-106.

6 Borodai V. P. Ekolohichna otsinka stanu dovkillia $\mathrm{v}$ zonakh vyrobnytstva produktsii ptakhivnytstva / V. P. Borodai, O. V. Tertychna, M. P. Keivan, O. P. Bryhas, I. V. Masberh, O. I. Mineralov // Suchasne ptakhivnytstvo. - 2014. - № 4. - S. 22-25.

7 Palapa N. V. Promyslove tvarynnytstvo: ekoloho-ekonomichni naslidky / N. V. Palapa, N. B. Pron, O. V. Ustymenko // Zbalansovane pryrodokorystuvannia. - 2016. - № 3. - S. 64-67.

8 Buzhyn O. O. Ekolohichna bezpeka: koefitsiient ekolohichnoi zbalansovanosti vnesennia orhanichnykh ta mineralnykh dobryv / O. O. Buzhyn // Naukovyi zhurnal «Molodyi vchenyi». - 2015. №2. Ch. I. - S. 127-130.

9 Shebanin V. S. Transformatsiia zemelnykh vidnosyn i zemlekorystuvannia v Ukraini / V. S. Shebanin, O. V. Shebanina, I. I. Chereven // Instytutsionalni zasady transformatsii v ahrarnii sferi: Zbirnyk materialiv Trynadtsiatykh richnykh zboriv Vseukrainskoho konhr. vchen. ekonomistivahrarnykiv (m. Kyiv, 20-21.06.2011) / Redkol.: P. T. Sabluk ta in. - K.: NNTs IAE, 2011. - S. 462-466.

10 Vnesennia mineralnykh ta orhanichnykh dobryv pid urozhai silskohospodarskykh kultur u 2017 rotsi [Elektronnyi resurs] - Rezhym dostupu: http://www.ck.ukrstat.gov.ua/source/arch/2018/dobriva _18.pdf.

11 Statystychnyi shchorichnyk Ukrainy za 2016 rik / Derzh. komitet statystyky Ukrainy. - K.: 2017. $-610 \mathrm{~s}$.

Надійшла до редакиії 3 травня 2019 р. 